\title{
特集／テイッシュウェルデイング
}

\section{Tissue Weldingの観点からみた血管吻合術 Vascular anastamosis by laser tissue welding}

岡田 昌義, 清水 一太, 生田 博, 辻 義彦, 吉田 正人 神戸大学医学部第 2 外科

Masayoshi OKADA, Kazuta SIMIZU, Hiroshi IKUTA, Yoshihiko TSUJI and Masato YOSHIDA

Department of Surgery, Division II Kobe University, School of Medicine

\section{要 旨}

Tissue weldingにより血管吻合が可能かどうかを確認する目的で基礎的研究を行った。その 結果， $\mathrm{CO}_{2}$ レーザーを応用すれば出力20〜 $40 \mathrm{~mW}$ ，照射時間 $6 〜 12 \mathrm{sec} / \mathrm{mm}$ という至適な条件下 で十分血管吻合が可能であるという事実が立証された。かかる成果に基づいて臨床例110例に応 用し，本法に上る血管吻合術が十分可能であり，良好な成績がえら机ることが確認さ机た。今後， この tissue welding 法は大いに普及するもの上考元られた。

キーワード：ティッシュウェルディング，低出力 $\mathrm{CO}_{2}$ レーザー，耐圧並びに抗張力テスト，間 歇性跛行, 虚血性心疾患

\section{Abstract}

The aim of this study was to evaluate an availability of vascular anastomosis by laser tissue welding. For this study $\mathrm{CO}_{2}$ laser was applied for tissue welding, because of minimized tissue reaction. Optimal conditions of laser vascular anastomosis were 20 $40 \mathrm{~mW}$ in output and $6 \sim 12 \mathrm{sec} / \mathrm{mm}$ in irradiation time.

Based on the excellent experimenatal studies, $\mathrm{CO}_{2}$ laser was employed for 110 patients with intermittent claudication, renal failure and anginal attack. There are no complications for laser irration. From these findings, technique of the tissue welding by laser might be used in vascular surgery especially for small-caliber vessels.

Key words : Tissue welding, low power $\mathrm{CO}_{2}$ laser, pressure stress and tensile strength tests, intermittent claudication, anginal attack.

\section{はじめに}

著者らは1980年初期から心臓血管外科領域においてわ が国でいち早くレーザーを導入し，種々基礎的研究を重 ねてきた。この際生体組織は低出力のレーザ一熱に当れ ば組織が融解し，凝固する事実を見出した。その後 $\mathrm{CO}_{2}$ レーザーを用いてtissue weldingの状況を検索し，血
管吻合が可能が゙うかを目的として研究した。その結果， 満足すべき成績がえられたので実地臨床面にも応用し， その実績も立証さ机たので報告する”。

\section{1) Tissue weldingの目的}

冠動脈のバイパス術のごとき細小血管の血行再建術を 
行った際，遠隔期の開存率を高く維持することは現時点 における最大の関心事といえる。そのためには血管吻合 術において縫合系をできるだけ少なくし，これによる異 物反応を極力抑えることが得策ではないかと考え、これ にレーザーを応用しだ2。

\section{2) レーザーエネルギーと血管組織との反応}

レーザーの種類としては組織への反応が軽微である $\mathrm{CO}_{2}$ を使用した。

対象として成犬を用いて全身麻疩下し，頸動・静脈， 大腿部・静脈の小片を摘出した。その後, 小動脈に対し てはレーザー出力 $20 ， 40 ， 60,80 \mathrm{~mW}$ ，照射時間 5，10， $20 \mathrm{sec}$, 壁の薄い静脈に対しては, 動脈の照射時間の半 分としてtissue weldingの状況を観察した

\section{3) Tissue weldingの適切な条件}

上述の条件下で組織反応を検討したが，その状況を以 下の 3 型に分類した。すなわち，I型：レーザー照射に より血管壁に凝固層のみが存在するもの，II 型：凝固層 之炭化層とが認められが、これらの層が血管壁の $1 / 2$ 以下 のもの, III型: 組織への反応が強く組織欠損を伴うもの, などである。

これらの所見を総合的に判定したところ，血管吻合に 適切なtissue weldingの条件は、レーザー出力20〜40 $\mathrm{mW}$ ，照射時間 $6 〜 12 \mathrm{sec} /$ mmであることが確認された。 その後、この条件下で血管吻合を側々，端側並びに端々 吻合で施行したが、いずれの手段においても可能なこと が証明された ${ }^{2) 。 ~}$

\section{4) Tissue weldingによる血管吻合のポイント} 血管吻合の要点は以下の点での注意が必要である。す なわち、 a ) 吻合する血管の断端に数本の支持糸をかけ て接合させること， b) 吻合線上にレーザーの焦点光を ゆっくりとあてること，c） $\mathrm{CO}_{2} レ$ レ゙ーは水分等に吸 収されやすいので吻合線上は必ずdryに維持すること, などである。

\section{5 ）レーザ一血管吻合部位の強度について}

Tissue weldingによるレーザー吻合部の強度の点を 解明するために, レーザーと縫合糸による吻合直後の 20 個所について耐圧並びに抗張力テストを行って，その両 群を比較検討した。

a) 耐圧テスト

吻合した直後にnoradrenalinを 1 筒静注して動脈圧 を300mm Hgまで上昇させ，出血の有無を観察した。その
結果, 吻合直後に出血点がなければ, その後動脈圧の上 昇によってもほとんど出血しないことが確認された。吻 合直後の出血は支持系による倽孔からのものが大半を占 めたが、これはガーゼの圧迫で止血できた。

b) 抗張力テス卜

吻合直後に加重をかけて吻合部が離断するときの重量 で抗張力を算出した。その結果, レーザー吻合部での抗 張力は1034.2士103.9 g，縫合系によるそれは1103.7士 $144.8 \mathrm{~g}$ と, この両群間に有意差のない事実が判明し, レーザー吻合部が予想外に強固に癒合していることが証 明された。

\section{6) Tissue welding 部の組織像}

レーザーにより吻合した部位を光顕的に観察した。吻 合直後はレーザー熱によって外膜や中膜の弾性線維やコ ラーゲンが融解して，あたかも生体糊のようになり嘴合 している組織像が明らかに認められ、レーザーによって 良好に吻合されている事実が立証された。

経時的な变化をみると, fibroblastの增生が次第に強 くなり,少なくとも2カ月以降になると，吻合部はごく自 然な状態で虑合しているのがみられた。このような変化 は血管内視鏡下にも観察さ机、レーザーによってtissue weldingが十分に行わ机ているという過程が明らかに呈 示された。

一方では，縫合系による吻合部の組織像をも検討した が，縫合系の周りには異物巨細胞の出現が多数みられた。 これが要因となって, 後日, 過剩な肉芽形成が生じるこ とが確認された。このような現象が生じると細小血管の 吻合部ではとくに内腔の狭小化が惹起されることになり， 遠隔期における開存率に支障がみられる。以上の所見よ り、レーザーによるtissue weldingが優れているもの と考えられた。

このようにレーザーによるtissue weldingにより良 好に血管吻合が確実にできるのは，低出力 $\mathrm{CO}_{2} レ$ レ゙ー のエネルギーが内膜にまで到達しないために，内膜損傷 が生じないためであるという事実が立証されたのである。

\section{7 ）臨床例への応用}

基礎的研究でレーザーによるtissue weldingで血管 物合が可能であり，その有用性が確認されたので臨床例 に応用した。その総数は現在110症例(男性77例, 女性33 例）であり，血管吻合の籄所は135力所であっだ”。年 齢は18～80歳 (平均59歳)である。

a) 末梢動脈に対する応用

97症例, 122力所の末梢動脈に対してレーザーが応用 
された。そのtissue weldingの部位は大腿動・静脈， 滕窝動脈, 脛骨動脈, 足背動脈, 上腕動脈, 橈骨動脈之 バラエティに富んでいる。 $\mathrm{CO}_{2}$ レーザーの条件は出力 30 $\sim 60 \mathrm{~mW}$ (平均 $40 \mathrm{~mW}$ )，照射時間 $38 \sim 360 \mathrm{sec}$ (平均 5.8 $\mathrm{sec} / \mathrm{mm})$ でちった。臨床例の第 1 例目は1985年 2 月 21 日，慢性腎不全症例に対して橈骨動脈部で動・静脈端側 吻合が行われた。この症例はレーザー応用による血管の tissue welding法での世界における最初の臨床成功例 となった。その後末梢動脈ではbelow kneeの足背動脈 への血行再建術をもレーザーのtissue welding法を纫 用し，良好な成果がえられている。

b）冠動脈に対寸る応用

末梢動脈でレーザー応用に好結果がえられた後に，冠 動脈に応用した。現在その数は13症例であり，全例が男性 で年齢は39〜70歳（平均59歳）である。症状は，狭心症 あるいは心筋梗塞後狭心症を呈しており，冠動脈造影に て、いずれも多岐病変例であることが確認さ机た。グラ フトとして内胸動脈が 4 例に, 大伏在静脈が 9 例に使用 されたが，前下行枝の吻合にはレーザーによるtissue weldingが応用されだ。全例で経過は良好である。

冠動脈のように細い動脈の血行再建術では，物合部㹟 窄を防止することがとくに重要である。かかる目標に対 してはこのレーザーによるtissue weldingは合理的 であり，今後大いに賞用さ扟てよい術式と考元られる。

\section{おわりに}

血管のtissue welding としてCO:レーザーが十分そ の機能を発揮することを基礎的研究で確認した。Argon, Nd-YAGレーザーによって現在多くのレーザーが喠々

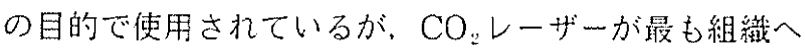
の深達度が軽微であることが特徽的であり，他の種類と 比較して最も有用之考えている。

このようにレーザーが血管のtissue welding として 応用できることを確認して臨床例に応用したが、特に緗 小血管の血行再建術にその特色が発揮されるものと考え られた。さらに，特記すべき点はレーザーによる血管吻 合部には狭窄が生じないことであるうと考えている。

このようにレーザーによるtissue welding法には画 期的なものがあり，今後大いに普及するものと考えてい る。

\section{文献}

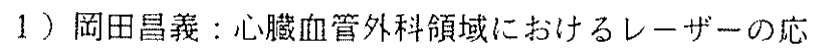
用について，日本レーザー医学会誌 $7 ： 42 ， 1986$

2) 岡田昌義, 清水一太, 生田博ほか: $\mathrm{CO}_{2}$ Laser老用
いる新しい血管吻合法 一基礎的並びに臨床的研 究一, 日本外科学会誌 $88: 390,1987$

3) Okada M, Shimizu K, Ikuta Het el:An alternative method of vascular anastomosis by laser : Experimental and clinical study. Lasers Surg \& Med. $7: 240,1987$

4) 岡田昌義, 清水一太, 生田博ほか: 血管接着剂として 有用な $\mathrm{CO}_{2}$ レーザーの応用一基䃈と臨床一、眽菅 学32: 1115, 1992 